\title{
ЗНАЧЕНИЕ ПОДПИСАНИЯ СОГЛАШЕНИЯ О СТРОИТЕЛЬСТВЕ ГАЗОПРОВОДА «ТУРЕЦКИЙ ПОТОК॥ ДЛЯ РАЗВИТИЯ ТОРГОВО-ЭКОНОМИЧЕСКИХ ОТНОШЕНИЙ РОССИИ С ТУРЦИЕЙ И ДРУГИМИ СТРАНАМИ ЮГО-ВОСТОЧНОЙ, ВОСТОЧНОЙ И ЦЕНТРАЛЬНОЙ ЕВРОПЫ
}

\begin{abstract}
Аннотация. Предметом (объектом) исследования являются перспективы развития торгово-экономических отношений России со странами Юго-Восточной, Восточной и Центральной Европы посредством экспорта российского природного газа в рамках проекта "Турецкий поток». Автор подробно рассматривает такой аспект темы, как невозможность осуществления проекта «Южный поток» в страны Юго-Восточной Европы. Особое внимание в статье уделяется сложному двухлетнему пути к подписанию в присутствии Президента России В.В. Путина и Президента Турции Р.Т. Эрдогана Соглашения между Правительством РФ и Правительством ТР по проекту «Турецкий поток». В целях проведения глубокого исследования и получения максимально полных и объективных выводов в основу труда положены исторический, логический, сравнительный и аналитический методы научного познания действительности, а также методологии системного анализа, структурно-функционального анализа, моделирования и прогнозирования. Статья представляет собой целостное, объединенное единым замыслом инновационное исследование перспектив взаимодействия России с Турцией и другими европейскими странами в газотранспортной сфере. Наиболее существенным результатом исследования является вывод автора о том, что подписание соглашения о строительстве газопровода «Турецкий поток» знаменует новый этап отношений между Россией и Турцией и открывает широкие горизонты взаимовыгодного российско-турецкого торгово-экономического сотрудничества.
\end{abstract}

Ключевые слова: Россия, Турция, Греция, США, Газпром, Боташ, Южный поток, Турецкий поток, ТрансАдриатический трубопровод, Южный газовый коридор.

Abstract. The research subject (object) is the prospects of development of trade and economic relations between Russia and the countries of Southeastern, Eastern and Central Europe on the base of Russian natural gas export via the TurkStream project. The author considers such aspect of the topic as the impossibility to realize the South Stream project in the countries of Southeastern Europe. Special attention is given to the complicated two-year's path to signing the TurkStream pipeline agreement between the Governments of the Russian Federation and Turkey in the presence of Russian President Vladimir Putin and the President of Turkey Recep Tayyip Erdoğan. In order to carry out a comprehensive study and obtain full and objective results, the author applies the historical, logical, comparative and analytical methods of cognition and the methodology of system analysis, structural and functional analysis, modeling and prognostication. The paper is a comprehensive innovative study, based on the idea of the prospects of interrelations between Russia and Turkey and other European countries in the gas transportation sphere. The author comes to the conclusion that the TurkStream pipeline agreement symbolizes the new stage of Russia-Turkey relations and expands the horizons of mutually beneficial cooperation of Russia and Turkey in the trade and economic sphere. Key words: TurkStream, South Stream, Botas, Gazprom, USA, Greece, Turkey, Russia, Trans-Adriatic Pipeline, Southern Gas Corridor.

$\mathrm{B}$ целях развития эффективных торгово-экономических отношений и плодотворного энергетического сотрудничества с европейскими государствами Россия заинтересована в экспорте природного газа в страны Юго-Восточной, Восточной и Центральной Европы.

До кризиса во взаимоотношениях России с Украиной беспрепятственный и бесперебойный экспорт российского природного газа в юго-восточном направлении с советских времен осущест- влялся по газотранспортной инфраструктуре транзитом через территорию Украины. В связи с неразрешимыми в настоящее время проблемами транзита природного газа по украинской территории Россия предпринимает усилия по проведению газопровода в страны Юго-Восточной Европы другим маршрутом, минуя территорию Украины. Первоначально Россия планировала осуществить проект строительства газопровода «Южный поток» по акватории Черного моря для поставки природного 
газа в Болгарию и через болгарскую территорию в другие страны Юго-Восточной Европы.

В связи с недостижением соглашения с Болгарией о прокладке газопровода по болгарской территории в августе 2014 года Россия отказалась от осуществления проекта строительства газопровода «Южный поток» в страны Юго-Восточной Европы через территорию Болгарии оценочной стоимостью 32 млрд евро (40 млрд долларов). Российская сторона обосновала отказ от проекта «Южный поток» теми обстоятельствами, что, вопервых, Евросоюз препятствует реализации данного проекта России, и, во-вторых, Болгария, подчиняясь позиции Евросоюза по этому вопросу, не дала разрешения на проведение газопровода по болгарской территории ${ }^{[1]}$.

В конце 2014 года Россия приняла решение о целесообразности строительства газопровода «Турецкий поток» для поставки российского природного газа в Турцию и через турецкую территорию в страны Юго-Восточной, Восточной и Центральной Европы. В настоящее время Турция является вторым после Германии покупателем российского природного газа. С июня 1987 года по декабрь 2014 года из России в Турцию поставлено более 349 млрд куб. м. природного газа, в частности в 2013 году объем поставленного российского природного газа составил 26,7 млрд куб. м. ${ }^{[2], ~ в ~} 2014-27,4$ млрд куб. м. ${ }^{[3]}$.

\section{Политико-правовые основы отношений между Россией и Турцией в газовой сфере}

Начало взаимоотношений между Россией и Турцией в газовой сфере было положено Соглашением о поставках природного газа в Турцию между Правительством СССР и Правительством Турецкой Республики от 18 сентября 1984 года ${ }^{[4]}$. В дополнение к вышеуказанному соглашению Россией и Турцией была принята Долгосрочная программа экономического, торгового, научно-технического сотрудничества между ССС и Турецкой Республикой от 26 декабря 1984 года ${ }^{[5]}$.

В 1990-е годы происходило активное развитие отношений между Россией и Турцией, которыми было подписано значительное число международно-правовых актов, направленных на создание прочной торговых, экономических, научно-технических и политических основ для развития взаимоотношений между странами в энергетической, в частности в газовой сфере:

Два договора, заложивших фундамент развития на долгосрочной основе широкомасштабного сотрудничество в области экономики, торговли, науки, техники и экологии:

- Договор о дружбе, добрососедстве и сотрудничестве между Союзом Советских Социалисти- ческих Республик и Турецкой Республикой от 12 марта 1991 года ${ }^{[6]}$ :

- Договор об основах отношений Российской Федерации и Турецкой Республики от 25 мая 1992 года ${ }^{[7]}$

и шесть соглашений:

- Соглашение между Правительством Союза Советских Социалистических Республик и Правительством Турецкой Республики о торговом, экономическом и научно-техническом сотрудничестве от 12 марта 1991 года ${ }^{[8]}$.

- Соглашение между Правительством Российской Федерации и Правительством Турецкой Республики о создании Смешанной межправительственной Российско-Турецкой комиссии по торгово-экономическому сотрудничеству от 14 мая 1992 года ${ }^{[9]}$;

- Соглашение между Правительством Российской Федерации и Правительством Турецкой Республики о научно-техническом сотрудничестве от 5 сентября 1992 года ${ }^{[10]}$;

- Соглашение между Правительством Российской Федерации и Правительством Турецкой Республики о культурном и научном сотрудничестве от 19 июля 1994 года ${ }^{[11]}$;

- Соглашение между Правительством Российской Федерации и Правительством Турецкой Республики о сотрудничестве в области энергетики от 15 декабря 1997 года ${ }^{[12]}$ и прилагающийся к нему

Протокол между Правительством Российской Федерации и Правительством Турецкой Республики о сотрудничестве в создании энергетического объекта на природном газе от 15 декабря 1997 года ${ }^{[13]}$;

- Соглашение между Правительством Российской Федерации и Правительством Турецкой Республики о поставках российского природного газа в Турецкую Республику через акваторию Черного моря от 15 декабря 1997 года ${ }^{[14]}$ и прилагающийся к нему

Протокол к Соглашению между Правительством Российской Федерации и Правительством Турецкой Республики о поставках российского природного газа в Турецкую Республику через акваторию Черного моря от 15 декабря 1997 года от 27 ноября 1999 года ${ }^{[15]}$.

На сегодняшний день между Россией и Турцией существуют две международно-правовые договоренности о продаже Россией Турции установленных объемов природного газа.

Первой договоренностью является Соглашение о поставках природного газа в Турцию между Правительством СССР и Правительством Турецкой Республики от 18 сентября 1984 года, согласно которому с 1987 года Россия поставляет природный 
газа в Турцию в объеме 6 млрд куб. м. ежегодно по контракту от 14 февраля 1986 года и 8 млрд куб. м. по контракту от 10 декабря 1996 года ${ }^{[16]}$.

Второй договоренностью является Соглашение между Правительством Российской Федерации и Правительством Турецкой Республики о поставках российского природного газа в Турецкую Республику через акваторию Черного моря от 15 декабря 1997 года, согласно которому поступление природного газа из России в Турцию в период 2000-2006 годы постепенно увеличивалось и достигло 14 млрд куб. м. С 2007 по 2025 год Россия обязана поставлять в Турцию 16 млрд куб. м. природного газа ежегодно.

Указанные в соглашении от 15 декабря 1997 года 16 млрд куб. м. природного газа Россия должна поставлять в Турцию дополнительно к ранее согласованным объемам природного газа в соответствии с соглашением от 18 сентября 1984 года, в том числе: 6 млрд куб. м. по контракту от 14 февраля 1986 года и 8 млрд куб. м. по контракту от 10 декабря 1996 года.

В соответствии с соглашением от 15 декабря 1997 года и протоколом к соглашению от 27 ноября 1999 года подписан контракт от 15 декабря 1997 года: с российской стороны - 000 «Газэкспорт» / ОАО «Газпром», с турецкой стороны - фирмой «Боташ».

Нефтяная трубопроводная корпорация «Боташ» ${ }^{[17]}$ учреждена в 1974 году Турецким нефтяным акционерным обществом ${ }^{[18]}$ в качестве дочерней нефте- и газопроводной торговой компании. С 1995 года «Боташ» стала полностью государственной компанией.

Первоначально «Боташ» была создана для строительства и управления нефтепроводом «Киркук-Джейхан». В настоящее время «Боташ» имеет право собственности и управляет нефтепроводами «Джейхан-Кырыккале», «Батман-Дёртьёл» и «Шелмо-Батман» ${ }^{[19]}$. С 1987 года «Боташ» осуществляет транспортные и торговые операции с природным газом. «Боташ» имеет право собственности и управляет газопроводной сетью длиной в 4500 километров, а также терминалом для хранения сжиженного природного газа «Мармара Энерглиси» ${ }^{[20]}$. «Боташ» является также участником международного нефтепровода «Баку-Тбилиси-Джейхан Пайплайн» ${ }^{[21]}$, «Араб Газ Пайплайн» ${ }^{[22]}$, а также участвует в проекте строительства газопровода «Набукко».

До 2007 года «Боташ» имела монопольное право на импорт природного газа, его дистрибуцию, торговлю и ценообразование ${ }^{[23]}$. В целях адаптации турецкого энергетического рынка к требованиям законодательства внутреннего энергетического рынка Евросоюза, являющейся условием присоединения Турции к Евросоюзу, и с согласия российской ОАО «Газпром» «Боташ», которая ранее имела исключительные права на импорт природного газа на рынок Турции, передала в 2007 году часть объемов своих контрактов на импорт природного газа четырем турецким частным компаниям. По просьбе турецкой стороны «Газпром экспорт» подписал в 2012 году с частными турецкими компаниями новые контракты на поставку до 2042 года российского природного газа в Турцию в объеме до 6 млрд куб. м. ежегодно, суммарный объем которых полностью соответствует объему природного газа по контракту «Газпрома» с «Боташ» от 14 февраля 1986 года. По новым контрактам российский природный газ поставляется в Турцию с 1 января 2013 года.

В 2007 году к торговле на внутреннем газовом рынке Турции были допущены «Ройал Датч Шелл» ${ }^{[24]}$ и «Босфорус Газ Корпорейшн» ${ }^{25]}$. «Босфорус Газ Корпорейшн» ${ }^{[26]}$ учреждена в Стамбуле в 2003 году; в 2004 году акционером «Босфорус Газ Корпорейшн» стала «Газпром Германия»- дочерняя компания «Газпрома». Оставшаяся часть акций «Босфорус Газ Корпорейшн» принадлежит «Тур Энерджи».

\section{Существующая газотранспортная инфраструктура между Россией и Турцией}

Для выполнения обязательств России по имеющимся соглашениям о поставке природного газа в Турцию «Газпромом» создана газотранспортная инфраструктура. Для реализации первого российско-турецкого соглашения о поставках природного газа от 18 сентября 1984 года построен «Транс-Балканский» газопровод ${ }^{[27]}$, проходящий транзитом по территории Болгарии и Румынии, а в постсоветское время также по территории Украины и Молдовы. Для реализации второго российско-турецкого соглашения о поставках природного газа от 15 декабря 1997 года построен газопровод «Голубой поток».

Согласно протоколу к соглашениюот 27 ноября 1999 года поставки природного газа в Турцию, предусмотренные соглашением от 15 декабря 1997 года, осуществляются по магистральному газопроводу «Голубой поток», проходящему по маршруту от поселка Изобильное Ставропольского края России до города Самсун в Турции через акваторию Черного моря. Строительство и эксплуатация участка газопровода по территории России от поселка Береговой Краснодарского края, включая компрессорную станцию, через акваторию Черного моря и по территории Турции до пункта соединения с турецкими газовыми сетями в районе города Самсун осуществляются компанией, учрежденной ОАО «Газпром». 
Согласно протоколу к соглашению от 27 ноября 1999 года учрежденная ОАО «Газпром» компания является собственником морского участка газопровода «Голубой поток». Деятельность данной газопроводной компании подлежит налогообложению только в Российской Федерации. Компания, собственник морского участка газопровода «Голубой поток», освобождена от уплаты действующих или принятых в будущем следующих налогов: налога на имущество (недвижимость), налога на добавленную стоимость, налогов и сборов в дорожные фонд и иных подобных налогов и сборов, непосредственно связанных с реализацией соглашения. Компания, собственник морского участка газопровода «Голубой поток», ежемесячно уплачивает налог на прибыль (доход), входящий в систему налогов России по фиксированной ставке 0,1 доллара США за каждую 1000 куб. м. траспортированного природного газа.

Согласно протоколу к соглашению от 27 ноября 1999 года ОАО «Газпром» и 000 «Газэкспорт» по деятельности, связанной с поставками российского природного газа по трубопроводу «Голубой поток», освобождены от уплаты налога на добавленную стоимость и вывозной таможенной пошлины на природный газ. После 31 декабря 2015 года акциз по экспортируемому в рамках соглашения от 15 декабря 1997 года российскому природному газу производится ОАО «Газпром» в общеустановленном порядке.

В течение 25 лет до 2022 года Россия должна поставить в Турцию по газопроводу «Голубой поток» 365 млрд куб. м. газа в на условиях «бери или плати» по цене на газ, привязанной к рыночной цене на нефть $^{[28]}$. За период эксплуатации газопровода «Голубой поток» прямые поставки природного газа из России в Турцию составили более 110 млрд куб. м. ${ }^{[29]}$.

\section{Хроника взаимодействия между Россией и Турцией по подписанию соглашения о строительстве газопровода «Турецкий поток»}

1 декабря 2014 года во время визита в Турцию Президента Российской Федерации В.В. Путина в присутствии президентов обоих государств Председателем Правления ОАО «Газпром» А.Миллером и Председателем Совета директоров «Боташ» М. Конук подписан Меморандум о взаимопонимании о строительстве газопровода «Турецкий поток» по акватории Черного моря в Турцию ${ }^{[30]}$.

Особенность договоренности между Россией и Турцией в отношении строительства газопровода «Турецкий поток» заключается в том, что за подписанием вышеуказанного меморандума не последовало заключение межправительственного соглашения, что объяснялось отсутствием утверж- денного кабинета министров Турции.

Проектная мощность газопровода «Турецкий поток», состоящего из четырех ниток, общей протяжённостью около 1100 километров составляет 63 млрд куб. м. природного газа в год ${ }^{[31]}$, из которых 14 млрд куб. м. предназначены для турецких потребителей. Для доставки оставшихся около 50 млрд куб. м. (точнее 47 млрд куб. м. ${ }^{[32]}$ ) потребителям стран Юго-Восточной Европы на границе Турции с Грецией планируется построить хаб, из которого газотранспортным компаниям государств-членов EC Россия предлагает закупать газ. Планируемое потребление природного газа Грецией составляет 4 млрд куб. м. ${ }^{[33]}$.

Сообщается, что Министр энергетики А. Новак заявил: «В настоящее время «обсуждается строительство двух ниток пропускной способность по 15,75 млрд куб. м. газа в год каждая. Первая нитка будет обеспечивать топливом турецких потребителей, вторая может пойти в Европу» ${ }^{[34]}$. «Газпром» оценивает строительство первой нитки газопровода «Турецкий поток» мощностью 15,75 млрд куб. м. природного газа в ежегодно, в 3,3 млрд евро; для сравнения - стоимость проекта «Северный поток - 2» предположительно составит 9,9 млрд евро ${ }^{[35]}$.

Первоначально сообщалось, что поставки по газопроводу «Турецкий поток» начнутся в декабре 2016 года, и что итальянская фирма «Сайпем» будет проводить прокладку труб в подводной части маршрута $^{[36]}$.

Пунктом отправки газа по трубопроводу «Турецкий поток» на территории России будет компрессорная станция «Русская» в Анапском районе Краснодарского края, пунктом доставки на территории Турции - город Ипсила недалеко от границы с Грецией ${ }^{[37]}$.

27 января 2015 года Главой «Газпрома» А. Миллером и Министром энергетики и природных ресурсов Турции Т. Йылдызом согласован маршрут газопровода «Турецкий поток». 660 км газопровода пройдут по маршруту проекта «Южный поток», по которому уже завершены инженерно-изыскательские работы, и поэтому, по словам А. Миллера, «сроки реализации «Турецкого потока» могут быть очень короткими» ${ }^{[38]} .250$ км будут проведены по новому маршруту в направлении европейской части Турции» ${ }^{[39]}$. По результатам встречи российская и турецкая стороны договорились подготовить межправительственное соглашение по газопроводу к подписанию во втором квартале 2015 года.

7 февраля 2015 года А. Миллер и Т. Йылдыз обследовали на месте и согласовали маршрут сухопутного участка газопровода «Турецкий поток» длиной 180 километров по территории Турции и определили точки: 
1. Выхода газопровода из моря на сушу в пункте Кыйыкёй,

2. Сдачи газа для турецких потребителей в пункте Люлебургаз,

3. Выхода на турецко-греческую границу в пункте Ипсала ${ }^{[40]}$.

22 июня 2015 года Турция выдала разрешение на инженерные изыскания по морскому участку «Турецкого потока», которое предусматривает проведение исследований по первой нитке газопровода в исключительной экономической зоне, а также в территориальных водах Турции ${ }^{[41]}$.

31 июля 2015 года Министр энергетики России А. Новак сообщил, что с турецкой стороной достигнута договоренность о скидке в размере $10,25 \%{ }^{[42]}$, которая для Турции составит экономию в 1 млрд долларов ежегодно и документ о предоставлении Турции скидки на газ будет подписан одновременно с соглашением по газопроводу «Турецкий поток» ${ }^{[43]} .6$ октября 2015 года Глава «Газпрома» А. Миллер заявил, что компания не будет строить третью и четвертую нитки газопровода «Турецкий поток» ${ }^{[44]}$.

Историю взаимоотношений между Россией и Турцией изменило трагическое событие, происшедшее 24 ноября 2015 года, когда истребителем F-16C BBC Турции был сбит фронтовой бомбардировщик Су-24М под командованием подполковника ВКС России Олега Пешкова.

28 ноября 2015 года В.В. Путин подписал Указ Президента РФ от 28.11.2015 № 583 «0 мерах по обеспечению национальной безопасности Российской Федерации и защите граждан Российской Федерации от преступных и иных противоправных действий и о применении специальных экономических мер в отношении Турецкой Республики» ${ }^{[45]}$, которые включают, в том числе приостановку работы российско-турецкой межправительственной комиссий по торгово-экономическому сотрудничеству $^{[46]}$.

Приостановка работы вышеуказанной межправительственной комиссий, согласно заявлению Министра энергетики России А. Новака, повлекла за собой приостановку переговоров по выработке межправительственного соглашения по строительству газопровода «Турецкий поток» ${ }^{[47]}$. В то же время враждебное России действие Турции и ответная реакция России не сказались негативно на функционировании газопровода «Голубой поток»[48].

Комментируя содержание переговоров с Премьер-министром Израиля Б. Нетаньяху 7 июня 2016 года Президент РФ В.В. Путин заявил относительно трубопроводов для экспорта российского газа по акватории Черного моря: «Есть известные трудности политического характера с Турцией, это известно. Но мы окончательно не отказывались ни от одного из проектов, ни от «Южного потока», ни от «Турецкого потока». Нам нужна только ясная позиция Еврокомиссии - ясная, понятная, однозначно понимаемая. Этого нет пока ни по одному из этих проектов» ${ }^{[49]}$.

27 июня 2016 года Президент Турецкой Республики Р.Т. Эрдоган направил послание Президенту России В.В. Путину с извинением за сбитый 24 ноября 2015 года самолет ВКС РФ и выразил желание нормализовать отношения между Турцией и Россией. 29 июня 2016 года состоялся телефонный разговор между Президентом России В.В. Путиным и Президентом Турции Р.Т. Эрдоганом, после которого В.В. Путин дал поручение Правительству РФ приступить к переговорам с Турцией с целью возобновления сотрудничества в тех областях, которые стали объектом ограничений ${ }^{[50]}$.

26 июля 2016 года Заместитель Председателя Правительства России А. Дворкович по поручению Председателя Правительства России Д.А. Медведева, подписавшего решение о возобновлении работы межправительственной комиссии, провел переговоры с Вице-премьером Турецкой Республики М. Шимшеком, по завершении которых осветил вопросы, которые обсуждались на российской-турецкой встрече. Относительно газопровода «Турецкий поток» А. Дворкович отметил, что «турецкая сторона подтвердила открытость для возобновления диалога на эту тему»; проект находится на ранней стадии, «тем не менее, при доброй воле сторон и здесь можно продвинуться достаточно быстро» ${ }^{[51]}$.

8 августа 2016 года, накануне визита в Россию, Президент Турции Р.Т. Эрдоган дал интервью Первому заместителю Генерального директора TACC М. Гусману, в котором изложил свое видение перспективы отношений между Турцией и Россией. Относительно реализации проекта «Турецкий поток» Президент Турции Р.Т. Эрдоган заявил о готовности «незамедлительно сделать шаги в направлении реализации этого проекта, обсудить его и принять решение. Каких-либо препятствий этому нет. Единственной препоной явилось это известное печальное событие. В настоящий момент больше всего газа мы приобретаем у России. И в этом вопросе у нас могут быть совместные шаги, поскольку Турция активно использует природный газ в промышленном производстве. Потребление увеличится. Как Вам известно, мы также работаем по проекту «Транс-Анатолийского» газопровода. Однако ввиду того, что речь идет о поставках газа в Европу, у европейцев также большие ожидания. По факту реализации и «Транс-Анатолийского» газопровода, и «Турецкого потока» возникнет совершенно другая картина. По данным на конец июля 2016 года, объем природного газа, импортированного из России, составил 12,5 млрд кубометров. Это 
показывает, насколько важным экономическим партнером в данной сфере является Турция» ${ }^{[2]}$.

Решающим шагом в направлении нормализации отношений между двумя странами явилась встреча и переговоры между Президентом России В.В. Путиным и Президентом Турции Р.Т. Эрдоганом 9 августа 2016 года в Санкт-Петербурге, в Константиновском дворце ${ }^{[53]}$. Во время визита в Россию Президента Турции Р.Т. Эрдогана сопровождали отраслевые министры и руководители ведущих компаний Турции, которые заявили о намерении активно участвовать в проекте строительства газопровода «Турецкий поток». Президент Турции P.T. Эрдоган заявил на пресс-конференции по итогам переговоров с Президентом России В.В. Путиным: «Одним из очень серьёзных шагов является «Турецкий поток». Он будет воплощён в жизнь в виде двух веток» ${ }^{[5]}$.

31 августа 2016 года Глава «Газпрома» А. Миллер и Министр энергетики и природных ресурсов Турции Б. Албайрак договорились о завершении в кратчайшие сроки процедуры выдачи всех необходимых разрешений для начала реализации проекта «Турецкий поток» ${ }^{[5]}$.

В начале сентября 2016 года «Газпром» получил первые разрешения турецких властей по газопроводу «Турецкий поток» после нормализации отношений между Россией и Турцией[56]. По сообщению «Газпрома» от 29 сентября 2016 года, «Газпром» получил разрешение на проведение изыскательских работ по двум ниткам морского участка газопровода «Турецкий поток» в территориальных водах Турции. Реагируя на данное событие Глава «Газпрома» А. Миллер заявил: «Следует отметить конструктивное, оперативное взаимодействие с турецкими партнерами. Работа по проекту «Турецкий поток» идет в отличном темпе. Получено важное очередное разрешение для его реализации ${ }^{[57]}$.

30 сентября 2016 года Министр энергетики России заявил, что соглашение между Россией и Турцией о поставках российского газа по газопроводу «Турецкий поток», предположительно, будет подписано в Стамбуле во время проведения Всемирного энергетического конгресса, который будет проходить октябре 2016 года: «Рассчитываем, если все будет в порядке, если до конца согласуем, то было бы целесообразно подписать как раз на международном энергетическом конгрессе» ${ }^{[58]}$.

5 октября 2016 года, накануне визита Президента России В.В. Путина в Турцию и предстоящей личной встречи на Всемирном энергетическом конгрессе 10 октября 2016 года в Стамбуле по инициативе Президента Турции Р.Т. Эрдогана состоялся телефонный разговор между президентами двух стран, во время которого В.В. Путин и Р.Т. Эрдоган выразили готовность двух стран к «реализации крупных совместных проектов в энергетической сфере - в частности строительства первой турецкой АЭС «Аккую» и газопровода «Турецкий поток» ${ }^{[59]}$.

\section{Позиции потенциальных стран-транзитеров российского газа трубопровода «Турецкий поток»}

Потенциальными странами-транзитерами и потребителями российского газа трубопровода «Турецкий поток» являются следующие за Турцией: Греция, Бывшая югославская Республика Македония, Сербия, Венгрия и Австрия. 7 апреля 2015 года министры иностранных дел этих стран, за исключением Австрии, на встрече в Будапеште в присутствии представителя Еврокомиссии обсудили перспективу участия в проекте «Турецкий поток» ${ }^{[60]}$. Должностные лица пяти европейских стран подписали Совместную декларацию об усилении энергетического сотрудничества в поддержку «коммерчески жизнеспособного варианта маршрута и источника диверсификации для доставки природного газа из Турецкой Республики через территории наших стран в страны Центральной и Юго-Восточной Европы», а также другие страны, что позволит государствам-участникам:

- поддержать энергетические рынки Турции, Европейского Союза и договаривающихся сторон Энергетического сообщества посредством Южного газового коридора;

- работать над новыми возможностями для создания регионального экономического развития через соединяющие инфраструктуры природного газа указанных стран с финансовой помощью Европейского Союза;

- приветствовать в духе сотрудничества желание других стран региона принять участие в этих усилиях;

- дополнить эксплуатацию мощностей газовых хранилищ целями содействия торговле, обеспечения сезонной балансировки и повышения безопасности энергообеспечения в случае срыва поставок газа.

В совместном документе отдельно указано, что декларация подтверждает только политическое намерение, и что необходим дальнейший обмен мнениями и диалог между участвующими государствами, а также заинтересованными компаниями ${ }^{[61]}$.

Позиция Греции, следующей за Турцией по предполагаемому маршруту газопровода «Турецкий поток», заключается в готовности активно участвовать в выгодном для бюджета Греции проекте «Турецкий поток».

Особенность положения Греции по этому вопросу заключается в том, что на позицию Греции 
оказывают влияние США, заинтересованные, вопервых, в участии Греции в конкурирующем и поддерживаемом Западом проекте строительства газопровода «Транс-Адриатический» трубопровод, который должен стать частью трубопроводной системы «Южный газовый коридор», предназначенной для поставки природного газа из Азербайджана и центрально-азиатских прикаспийских стран, и, во-вторых, в неучастии Греции в проекте строительства газопровода «Турецкий поток» для поставки природного газа из России. США аргументируют свою позицию тем, что это будет способствовать диверсификации и конкуренции энергообеспечения Евросоюза, что приведет к повышению энергетической безопасности европейских стран.

Проявлением вышеуказанной позиции США в отношении участия Греции в проекте строительства газопровода «Турецкий поток» является встреча 8 мая 2015 года Специального представителя Госдепартамента США по международным энергетическим делам А.Дж. Хохштайна в Афинах с Министром иностранных дел Греции Н. Котциасом и Министром энергетики Греции П. Лафазанисом ${ }^{[62]}$, на которых А.Дж. Хохштайн информировал греческую сторону о поддержке США участия Греции в проекте строительства «ТрансАдриатического» трубопровода ${ }^{[63]}$. Согласно проекту «Транс-Адриатический» трубопровод протяженностью 870 километров для поставки газа из Азербайджана через Грузию, Турцию, Грецию, Албанию и далее по дну Адриатического моря в Италию будет соединен с «Транс-Анатолийским» трубопроводом ${ }^{[64]}$ в месте Кипой на границе Греции с Турцией ${ }^{[65]}$. В настоящее время акционерами «Транс-Адриатического» трубопровода являются «Бритиш Петролеум», которая владеет 20\% акций; азербайджанская государственная компания «СОКАР» ${ }^{[66]}-20 \%$ акций; норвежская «Статойл» ${ }^{[67]}-$ $20 \%$; бельгийская «Флюксис» ${ }^{68]}-19 \%$; испанская «Энагаз» ${ }^{[69]}-16 \%$; швейцарская «Акспо» ${ }^{[70]}-5 \%$.

Проект строительства газопровода «ТрансАдриатического» трубопровода является составной частью проекта строительства трубопровода «Южный газовый коридор». Церемония закладки трубопровода «Южный газовый коридор» состоялось 20 сентября 2014 года в Баку ${ }^{[71]}$. Маршрут «Южного газового коридора» проложен параллельно уже действующему газопроводу «Баку-ТбилисиЭрзурум». На грузинской территории в Гардабани газопровод будет подключен к существующей насосной станции. Далее газ будет направляться по уже имеющейся трубопроводной системе.

Проект строительства трубопровода «Южный газовый коридор» с планируемым объемом инвестирования в размере 45 млрд долларов сформировался как альтернатива проекта строительства газопровода «Набукко», не решившего проблем инвестирования, для поставки природного газа из Азербайджана и других стран Каспийского региона через Грузию и Турцию в Европу. Планируемый объем поставок азербайджанского газа по «Южному газовому коридору», которые, по предварительным оценкам, должны начаться в Турцию в 2018 году и далее в другие европейские страны в 2019 году, составит первоначально 16 млрд куб. м. газа в год и в дальнейшем увеличится до 20 млрд куб. м. в год. Азербайджан заинтересован в поставках газа по «Южному газовому коридору», в том числе для того, чтобы компенсировать постепенное снижение доходов от экспорта нефти.

На пресс-конференции по результатам встречи А.Дж. Хохштайн заявил: « Турецкого потока» не существует. Нет консорциума для его строительства, нет согласия для его строительства. ... В настоящее время мы должны сосредоточить наше внимание на том, что важно - на трубопроводе, на который мы уже дали свое согласие, Греция уже дала согласие. ... Диверсификация, в конечном счете, лучший способ создать безопасность энергообеспечения. А это означает, что Вам должно быть разрешено ввозить газ, который является не российским, просто чтобы была конкуренция. Это также уменьшило бы шансы использования энергии в качестве политического рычага» ${ }^{[72]}$.

А.Дж. Хохштайн также отметил положительные стороны альтернативного российскому газу из Азербайджана: «Новый источник, новое предложение, новый путь доставки. И это не единственная страна, которая доминирует в инфраструктуре и производстве газа; это многие компании, различные консорциумы, разные страны..., ни один элемент не может разрушить это или использовать его как рычаг» ${ }^{[3]}$. По мнению А.Дж. Хохштайна, Россия не заинтересована помочь Греции выпутаться из многомиллиардного долга, а «Турецкий поток» - «это не экономический проект», а «только политика» ${ }^{[7]}$.

В сообщении «Нью-Йорк Таймс» о встрече Специального представителя США по международным энергетическим делам А.Дж. Хохштайна с официальными лицами Греции говорится: «Соединенные Штаты, предпринимая международные усилия с целью формирования экономической и геополитической ориентации Греции, подталкивают левое правительство в Афинах к противостоянию энергетическим инициативам России. Посланник Госдепартамента призвал Грецию поддержать поддерживаемый Западом проект, который соединит Европу с запасами природного газа в Азербайджане, и не соглашаться на проталкиваемый Москвой проект газопровода. Торговая дуэль, напоминающая противостояние холодной войны, происходит в то время, как обремененная задолженностью Греция 
отчаянно ищет новые источники дохода, подобные тому, который мог бы принести трубопровод» ${ }^{[55]}$.

На телеконференции 8 мая 2015 года с европейскими журналистами на вопрос: «Специальный представитель Государственного департамента США по международным энергетическим делам А.Дж. Хохштайн на встрече с официальными лицами Греции выразил озабоченность относительно проекта газопровода «Турецкий поток», который, по мнению греков, будет полезен для экономики Греции. Есть ли у Вас альтернативный план, чтонибудь другое, что повысит их диверсификации и, конечно, в то же время будет полезен для экономики Греции?»- Заместитель Государственного секретаря США А.Дж. Блинкен ${ }^{[76]}$ уклончиво ответил: «Мы и каждая страна в Европе очень заинтересованы в энергетической диверсификации с точки зрения источников, с точки зрения типов, с точки зрения путей доставки, что приведет к большей энергетической безопасности. С этим прицелом мы относимся к данным вопросам, на этом мы фокусируем наши разговоры с европейскими партнерами о развитии более энергобезопасного будущего» ${ }^{[77]}$.

Несмотря на противодействие США Греция делает шаги в сторону развития энергетических отношений с Россией в рамках проекта строительства газопровода «Турецкий поток». В настоящее время 65\% ежегодно потребляемого Грецией природного газа поставляется из России. В то же время, несмотря на договоренность 2014 года о снижении цены на газ на 15\% между греческой государственной компанией DEPA, являющейся импортером и дистрибьютером природного газа, и российским «Газпромом», Греция закупает российский газ по самой дорогой цене в Европе ${ }^{[78]}$.

18 июня 2015 года состоялась встреча Министра энергетики России А. Новака и Министра производственной реформы, охраны окружающей среды и энергетики Греции П. Лафазаниса, на которой был подписан Меморандум о сотрудничестве при строительстве и эксплуатации газопровода «Турецкий поток» на территории Греции ${ }^{[79]}$. Через год, 8 апреля 2016 года на пресс-конференции в Москве Премьер министр Греции А. Ципрас подтвердил заинтересованность греческой стороны в финансировании российской стороной газопровода, который «будет брать природный газ с греко-турецкой границы с целью энергетической безопасности и автономии нашей страны, Греции, её развития. Кроме того, проекты такого калибра создают возможность стабилизации и безопасности в регионе в целом» ${ }^{[0]}$. А. Ципрас сделал отдельное заявление относительно названия будущего газопровода, указав на то, «что «Турецкого потока» на территории Греции не будет. Это будет греческий трубопровод. Турецкий трубопровод будет на террито- рии Турции. Чтобы это было ясно. ... Мы считаем, что мы не можем принять название «Турецкий поток», но мы считаем, что это как раз улучшит наши отношения с Турцией» ${ }^{[81]}$.

Позиция Болгарии заключается в том, что Болгария желает стать газовым хабом на Юго-Востоке Европы, наподобие Германии - на Северо-Западе Европы. Премьер министр Болгарии Б. Борисов заявил об этом 17 декабря 2015 года, накануне заседания Европейского совета ${ }^{[82]}$. Б. Борисов считает приоритетным для Болгарии не строительство газопровода «Южный поток», а создание газового хаба «Балканский» в окрестностях черноморского порта Варна мощностью 20 млрд куб. м. газа в год для хранения газа, как произведенного в Болгарии и Румынии, так и поступающего из греческоболгарского стыковочного узла, Азербайджана по «Южному газовому коридору» и из России. Это объясняет факт того, что Болгария не поддержала ряд восточно-европейских стран, выступивших против строительства второй нитки газопровода «Северный поток», которые опасаются, что в результате прекращения транзита российского газа через Украину потеряют соответствующий доход и будут поставлены перед проблемой создания новых трубопроводных систем для получения газа со стороны Германии ${ }^{[83]}$.

Выступая в Парламенте своей страны 13 января 2016 года Премьер министр Болгарии Б. Борисов заявил о необходимости реализовать «проект «Болгарский поток» со 100-процентной болгарской собственностью на трубопровод на территории Болгарии вместо проекта $50 \%$ на $50 \%$ с российской компанией» «Южный поток Болгария» ${ }^{[84]}$. «Мы будем приветствовать, если российская сторона согласится продавать газ на нашей границе. Нами будет соблюден Третий энергетический пакет и санкции Еврокомиссии» ${ }^{[85]}$, - заявил Премьер министр Болгарии. Эта предложение Болгарии стало предметом обсуждения 27-28 января 2016 года на заседании Болгарско-российской межправительственной комиссии по экономическому сотрудничеству, которая не собиралась предшествовавшие пять лет ${ }^{[86]}$.

\section{Перспективы развития торгово- экономических отношений между Россией и Турцией в газовой сфере}

До подписания нового российско-турецкого соглашения на поставку российского природного газа в Турцию между государствами существовали две международно-правовые договоренности: Соглашение о поставках природного газа в Турцию между Правительством СССР и Правительством Турецкой Республики от 18 сентября 1984 года и Соглашение между Правительством Российской Федерации 
и Правительством Турецкой Республики о поставках российского природного газа в Турецкую Республику через акваторию Черного моря от 15 декабря 1997 года.

В соответствии с вышеуказанными российскотурецкими договоренностям общий объем ежегодно поставляемого Россией в Турцию природного газа должен составлять 30 млрд куб. м., в том числе:

- 14 млрд куб. м. природного газа в соответствии с соглашением от 18 сентября 1984 года: 6 млрд куб. м. газа по контракту от 14 февраля 1986 года и 8 млрд куб. м. по контракту от 10 декабря 1996 года;

- 16 млрд куб. м. природного газа в соответствии с соглашением от 15 декабря 1997 года.

Согласно сведениям «Газпрома» в 2013 году Россия поставила Турции 26,7 млрд куб. м. природного газа, в $2014-27,4$ млрд куб. м. Сопоставление представленных данные указывает на то, что Россия в настоящее время поставляет в Турцию примерно на 3 млрд куб. м. природного газа меньше, чем обязана по международно-правовым обязательствам.

В целях реализации соглашений о поставке российского газа в Турцию построены и функционируют два газопровода:

- по соглашению 1984 года - «ТрансБалканский» газопровод, который проходит транзитом через Украину (в 2019 году истекает контракт «Газпрома» с украинским «Нафтогазом» о транзите газа через территорию Украины), Молдову, Болгарию и Румынию; - $\quad$ по соглашению 1997 года - газопровод «Голубой поток» по акватории Черного моря.

1 декабря 2014 года между российской и турецкой сторонами была достигнута договоренность о строительстве трубопровода «Турецкий поток» по акватории Черного моря для ежегодной поставки в Турцию и далее в другие европейские страны 63 млрд куб. м. природного газа. Особенность реализации проекта «Турецкий поток» заключается в том, что с момента подписания меморандума в декабре 2014 года до подписания соответствующего межправительственного соглашения в октябре 2016 года прошло почти два года.

Длительность срока согласования российскотурецких договоренностей в рамках проекта «Турецкий поток» объясняется сложным и противоречивым отношением Турции к России. В частности, в октябре 2015 года, во время государственного визита в Японию, Президент Турции Р.Т. Эрдоган заявил, что «Турция является главным покупателем российского газа, но если будет надо, она сможет получать его и из многих других мест. Это стало бы большой потерей для России» ${ }^{[87]}$. В ноябре 2015 года BBC Турции сбили выполнявший боевое задание в
Сирии самолет ВКС России. Данное событие привело к разрыву почти на год отношений между Россией и Турцией в рамках проекта «Турецкий поток».

Потенциальные страны-транзитеры и потребители российского газа трубопровода «Турецкий поток»: Турция, Греция, Бывшая югославская Республика Македония, Сербия, Венгрия и Австрия - открыто заявляют (за исключением Австрии) о готовности участвовать в данном российском проекте.

США и Евросоюз не поддерживают инициативу указанных стран участвовать в проекте «Турецкий поток» по поставке в Европу российского газа и, напротив, выражают заинтересованность Запада в участии, в первую очередь, Греции, в проекте «Транс-Адриатический» трубопровод, который должен стать частью трубопроводной системы «Южный газовый коридор», предназначенной для поставки природного газа из Азербайджана и центрально-азиатских прикаспийских стран. Греция, со своей стороны, заинтересована в участии, как в российском проекте «Турецкий поток», так и западном проекте «Транс-Адриатический» трубопровод.

10 октября 2016 года в Стамбуле во время проведения 23-го Всемирного энергетического конгресса в присутствии Президента России В.В. Путина и Президента Турции Р.Т. Эрдогана состоялось долгожданное подписание Соглашения между Правительством Российской Федерации и Правительством Турецкой Республики по проекту «Турецкий поток»[88]. Согласно достигнутой международноправовой договоренности будут построены две нитки газопровода по акватории Черного моря из России в Турцию и далее одна нитка по сухопутной территории Турции до границы с Грецией.

По итогам подписания документа Председатель Правления ПАО «Газпром» А. Миллер заявил: «Сегодня подписан исключительно важный документ - создана правовая основа для проекта «Турецкий поток». Беспрецедентно короткий срок, за который было подготовлено соглашение, свидетельствует о высокой заинтересованности обеих сторон в скорейшей реализации проекта. И это понятно - газопровод «Турецкий поток» значительно повысит надежность газоснабжения Турции, а также Южной и Юго-Восточной Европы» ${ }^{[89]}$.

Президент России В.В. Путин в своем выступлении специальной сессии 23-го Всемирного энергетического конгресса заявил: «Мы с турецкими партнёрами и с Президентом Эрдоганом подробно говорили и говорим, что намерены реализовать «Турецкий поток»» ${ }^{[90]}$. Подписание еще одного соглашения о поставках природного газа из России в Турцию знаменует новый этап взаимоотношений между двумя соседними странами и открывает новые горизонты взаимовыгодного российско-турецкого торгово-экономического сотрудничества. 


\section{Библиография:}

1. http://www.euractiv.com/section/global-europe/news/russia-says-south-stream-project-is-over/ of 02.12.2014.

2. http://www.gazprom.ru/press/news/2014/december/article208495/.

3. http://www.gazprom.ru/about/production/projects/pipelines/built/turk-stream/2014/.

4. http://allturkey.narod.ru/rusturkgaz1984.htm.

5. http://www.pravo.gov.ru/proxy/ips/?doc_itself=\&nd=102050471\&page=1\&rdk=0\&intelsearch=\%CE+\%E3\%EE\%F1\% F3\%E4\%E0\%F0\%F1\%F2\%E2\%E5\%ED\%ED\%EE\%E9+\%E3\%F0\%E0\%E6\%E4\%E0\%ED\%F1\%EA\%EE\%E9+\%F1\%EB $\%$ F3\%E6\%E1\%E5++\&link_id=4\#I0.

6. http://archive.mid.ru/bdomp/spd_md.nsf/0/69DE180856D3525A43257FE10046A789.

7. http://archive.mid.ru/bdomp/spd_md.nsf/0/A9BF1AA356E2ACB843257FE10046AD11.

8. http://archive.mid.ru/bdomp/spd_md.nsf/0/18FABFEDC0F291AD43257FE10046AE78; http://www.conventions.ru/ view_base.php?id=18932.

9. http://archive.mid.ru/bdomp/spd_md.nsf/0/26A671083603E1A543257FE10046AAC6; document/901912708; http://www.conventions.ru/view_base.php?id=18530.

10. http://xn--80abucjiibhv9a.xn--p1ai/\%D0\%BC\%D0\%B8\%D0\%BD\%D0\%B8\%D1\%81\%D1\%82\%D0\%B5\%D1\%80\%D1 \%81\%D1\%82\%D0\%B2\%D0\%BE/68/\%D1\%84\%D0\%B0\%D0\%B9\%D0\%BB/916/\%D0\%9C\%D0\%A1_\%D0\%9D\%D0 \%A2\%D0\%A1.pdf.

11. http://archive.mid.ru/bdomp/spd_md.nsf/0/B5B4FDF64CD4B87043257FE10046AE59.

12. http://archive.mid.ru/bdomp/spd_md.nsf/0/0A2F9D50CF3FFF3643257FE10046AAE5; http://www.conventions.ru/ view_base.php?id=4471.

13. http://archive.mid.ru/bdomp/spd_md.nsf/0/64642AF3317903E443257FE10046AEВА о строительстве электростанции мощностью 1400 Мвт.

14. http://archive.mid.ru/bdomp/spd_md.nsf/0/17A7AE83A505C40343257FE10046ADB4.

15. http://archive.mid.ru/bdomp/spd_md.nsf/0/7AC0A4FE053A138043257FE10046AD43.

16. http://www.gazpromexport.ru/partners/turkey/.

17. BOTAS Petroleum Pipeline Corporation (BOTAS), http://www.botas.gov.tr.

18. Türkiye Petrolleri Anonim Ortaklığı (TPAO), http://www.tp.gov.tr/tp5/.

19. Ceyhan-Kırıkkale Petrol Boru Hattı, Batman-Dörtyol Petrol Boru Hattı, Şelmo-Batman Ham Petrol Boru Hattı, http:// petrol-petroleum.blogspot.ru/p/mevcut-boru-hatlarimiz.html.

20. Marmara Ereğlisi Liquefied Natural Gas (LNG), http://www.istanbul34.com.tr/Web/Link/BOTAS\%20TERMINAL\%20 M\%20ERE\%C4\%9EL\%C4\%B0S\%C4\%B0\%20TKRD\%C4\%9E.htm.

21. Baku-Tbilisi-Ceyhan Pipeline, http://www.bp.com/en_az/caspian/operationsprojects/pipelines/BTC.html.

22. Arab Gas Pipeline, http://www.hydrocarbons-technology.com/projects/arab-gas-pipeline-agp/.

23. http://www.nabucco-pipeline.com/company/shareholders7/botas-as/botas.html.

24. Royal Dutch Shell, http://www.shell.com/.

25. http://uk.reuters.com/article/turkey-gas-shell-idUKL0219827620070202 of 02.02.2007.

26. Bosphorus Gaz Corporation, http://www.bosphorusgaz.com/.

27. «Транс-Балканский» газопровод начал функционировать в 1987 году.

28. http://www.vestifinance.ru/articles/60770 of 31.07.2015.

29. http://www.gazprom.ru/press/news/2014/december/article208495/.

30. http://www.gazprom.ru/press/news/2014/december/article208495 of 02.12 .2014$.

31. http://ria.ru/trend/Russia_transadriatic_pipeline_06122014/\#ixzz46MkVXa6W, http://www.euractiv.com/section/ global-europe/news/russia-says-south-stream-project-is-over/ of 02.12.2014.

32. http://www.euractiv.com/section/global-europe/news/tsipras-turkish-stream-will-have-another-name-on-greekterritory/ of 09.04.2016.

33. http://www.gazprom.ru/press/news/2014/december/article208495 of 02.12.2014.

34. https://www.vedomosti.ru/business/articles/2016/09/07/656082-gazprom-potok of 07.09.2016.

35. http://www.euractiv.com/section/europe-s-east/news/bypassing-ukraine-will-be-costly-for-gazprom-say-analysts/ 17.07.2015.

36. http://www.euractiv.com/section/europe-s-east/news/us-discourages-greece-from-turkish-stream/ of 13.05.2015; Saipem, http://www.saipem.com/sites/SAIPEM_en_IT/home/saipem-homepage.page.

37. http://www.gazprom.ru/press/news/2014/december/article208495 of 02.12 .2014 .

38. «Российская газета» от 16.11.2015, http://rg.ru/2015/11/16/potok1-site.html.

39. http://www.vestifinance.ru/articles/52461 от 27.01.2015.

40. http://www.gazprom.ru/press/news/2015/february/article217552/ of 07.02.2015.

41. http://www.gazpromexport.ru/projects/6/.

42. http://www.vestifinance.ru/articles/60770 of 31.07.2015.

43. http://crimea.ria.ru/world/20150804/1100605732.html of 04.08.2015.

44. http://crimea.ria.ru/world/20150804/1100605732.html of 04.08.2015.

45. https://www.consultant.ru/law/hotdocs/44842.html.

46. http://government.ru/media/files/GRARiHdNIWbl10wUg3LyPSAJPIDeTnLX.pdf.

47. «Российская газета», http://rg.ru/2015/12/03/novak-site.html of 03.12.2015; https://www.rt.com/business/324230gazprom-turkish-stream-cancellation/ of 02.12.2015; http://izvestia.ru/news/598076\#ixzz45hiPjq1Z of 03.12.2015; http://www.euractiv.com/section/europe-s-east/news/russia-shelves-turkish-stream-pipeline-project/ of 03.12.2015.

48. https://www.euractiv.com/section/europe-s-east/news/russia-shelves-turkish-stream-pipeline-project/ of 03.12.2015.

49. http://kremlin.ru/events/president/transcripts/52125 of 07.06.2016. 
50. http://kremlin.ru/events/president/news/52282 of 27.06.2016; http://tass.ru/politika/3514217; http://www. nytimes.com/2016/06/28/world/europe/russia-turkey-erdogan-putin.html?action=click\&contentCollection=Europe\& module=RelatedCoverage®ion=EndOfArticle\&pgtype=article of 27.06. 2016.

51. http://government.ru/news/24004/ от 26.07.3016.

52. http://tass.ru/opinions/interviews/3518845 of 08.08.2016; http://www.euractiv.com/section/energy/news/russiaturkey-rapprochement-revives-turkish-stream-pipeline-talks/of 09.08.2016.

53. http://www.kremlin.ru/events/president/news/52671 of 09.08.2016.

54. http://www.kremlin.ru/events/president/news/52675 of 09.08.2016.

55. http://www.gazpromexport.ru/projects/6/.

56. http://www.gazprom.ru/press/news/2016/september/article283085/ of 07.09.2016.

57. http://www.gazprom.ru/press/news/2016/september/article287217/ of 29.09.2016.

58. https://ria.ru/economy/20160930/1478235850.html.

59. http://www.kremlin.ru/events/president/news/53039 of 05.10.2016.

60. http://www.euractiv.com/section/energy/news/greece-macedonia-serbia-and-hungary-discuss-turkish-stream/ of 07.04.2015; http://kommersant.ru/doc/2703855 of 08.04.2015.

61. Joint Declaration on the Strengthening of Energy Cooperation of 07.04.2015, http://www.kormany.hu/en/ministryof-foreign-affairs-and-trade/photo-galleries/joint-declaration-on-the-strengthening-of-energy-cooperation; http:// www.mfa.gr/en/current-affairs/top-story/joint-declaration-on-the-strengthening-of-energy-cooperation-budapestapril-2015.html.

62. http://www.nytimes.com/2015/05/09/business/international/greece-us-russia-energy-pipeline.html of 09.05.2015.

63. Trans Adriatic Pipeline (TAP), http://www.tap-ag.com/.

64. Trans Anatolian Pipeline (TANAP), http://www.tanap.com/tanap-project/why-tanap/.

65. http://www.nytimes.com/2015/05/09/business/international/greece-us-russia-energy-pipeline.html of 09.05.2015.

66. SOCAR, http://www.socar.az/socar/az/home/.

67. Statoil, http://www.statoil.com/en/Pages/default.aspx.

68. Fluxys, http://www.fluxys.com/.

69. Enagás, http://www.enagas.es/portal/site/enagas.

70. Axpo, https://www.axpo.com/axpo/global/en/home.html.

71. http://www.bbc.com/russian/international/2014/09/140920_azerbaijan_europe_pipeline_launch.shtml.

72. http://oilprice.com/Latest-Energy-News/World-News/Greece-May-Be-Key-Player-In-European-Energy-Security.html of 11.05.2015.

73. http://oilprice.com/Latest-Energy-News/World-News/Greece-May-Be-Key-Player-In-European-Energy-Security.html, 11.05.2015.

74. http://oilprice.com/Latest-Energy-News/World-News/Greece-May-Be-Key-Player-In-European-Energy-Security.html, 11.05.2015.

75. http://www.nytimes.com/2015/05/09/business/international/greece-us-russia-energy-pipeline.html of 09.05.2015.

76. Antony J. Blinken, Deputy Secretary of State, Telephonic Press Briefing With European Journalists, http://www.state. gov/s/d/2015/242054.htm of 08.05.2015.

77. Antony J. Blinken, Deputy Secretary of State, Telephonic Press Briefing With European Journalists, http://www.state. gov/s/d/2015/242054.htm of 08.05.2015.

78. http://www.euractiv.com/section/global-europe/news/tsipras-turkish-stream-will-have-another-name-on-greekterritory/ of 09.04.2015.

79. http://www.gazpromexport.ru/projects/6/.

80. http://kremlin.ru/events/president/news/49220 of 08.04.2015.

81. http://kremlin.ru/events/president/news/49220 of 08.04.2015.

82. http://www.euractiv.com/section/energy/news/borissov-i-told-merkel-bulgaria-plans-pipeline-similar-to-nordstream-2/ of 17.12. 2015.

83. http://www.euractiv.com/section/energy/news/borissov-i-told-merkel-bulgaria-plans-pipeline-similar-to-nordstream-2/ of 17.12.2015.

84. http://www.euractiv.com/section/energy/news/south-stream-to-become-bulgarian-stream/ of 14.01.2016.

85. http://www.euractiv.com/section/energy/news/south-stream-to-become-bulgarian-stream/ of 14.01.2016.

86. http://www.euractiv.com/section/energy/news/south-stream-to-become-bulgarian-stream/ of 14.01.2016.

87. http://putin24.info/dvazhdy-v-odin-potok.html of 08.10.2015; http://m.novostimira.com/news-161460.html of 08.10 .2015

88. http://www.gazprom.ru/press/news/2016/october/article288205/ of 10.10.2016.

89. http://www.gazprom.ru/press/news/2016/october/article288205/ of 10.10.2016.

90. http://kremlin.ru/events/president/news/53062 of 10.10.2016.

\section{References (transliterated):}

1. http://www.euractiv.com/section/global-europe/news/russia-says-south-stream-project-is-over/ of 02.12.2014.

2. http://www.gazprom.ru/press/news/2014/december/article208495/.

3. http://www.gazprom.ru/about/production/projects/pipelines/built/turk-stream/2014/.

4. http://allturkey.narod.ru/rusturkgaz1984.htm.

5. http://www.pravo.gov.ru/proxy/ips/?doc_itself=\&nd=102050471\&page=1\&rdk=0\&intelsearch=\%CE+\%E3\%EE\%F1\% F3\%E4\%E0\%F0\%F1\%F2\%E2\%E5\%ED\%ED\%EE\%E9+\%E3\%F0\%E0\%E6\%E4\%E0\%ED\%F1\%EA\%EE\%E9+\%F1\%EB $\% \mathrm{~F} 3 \% \mathrm{E} 6 \% \mathrm{E} 1 \% \mathrm{E} 5++\& l i n k \_\mathrm{id}=4 \# \mathrm{I} 0$. 
6. http://archive.mid.ru/bdomp/spd_md.nsf/0/69DE180856D3525A43257FE10046A789.

7. http://archive.mid.ru/bdomp/spd_md.nsf/0/A9BF1AA356E2ACB843257FE10046AD11.

8. http://archive.mid.ru/bdomp/spd_md.nsf/0/18FABFEDC0F291AD43257FE10046AE78; http://www.conventions.ru/ view_base.php?id=18932.

9. http://archive.mid.ru/bdomp/spd_md.nsf/0/26A671083603E1A543257FE10046AAC6; document/901912708; http://www.conventions.ru/view_base.php?id=18530.

10. http://xn--80abucjiibhv9a.xn--p1ai/\%D0\%BC\%D0\%B8\%D0\%BD\%D0\%B8\%D1\%81\%D1\%82\%D0\%B5\%D1\%80\%D1 \%81\%D1\%82\%D0\%B2\%D0\%BE/68/\%D1\%84\%D0\%B0\%D0\%B9\%D0\%BB/916/\%D0\%9C\%D0\%A1_\%D0\%9D\%D0 \%A2\%D0\%A1.pdf.

11. http://archive.mid.ru/bdomp/spd_md.nsf/0/B5B4FDF64CD4B87043257FE10046AE59.

12. http://archive.mid.ru/bdomp/spd_md.nsf/0/0A2F9D50CF3FFF3643257FE10046AAE5; http://www.conventions.ru/ view_base.php?id=4471.

13. http://archive.mid.ru/bdomp/spd_md.nsf/0/64642AF3317903E443257FE10046AEBA o stroitel'stve elektrostantsii moshchnost'yu 1400 Mvt.

14. http://archive.mid.ru/bdomp/spd_md.nsf/0/17A7AE83A505C40343257FE10046ADB4.

15. http://archive.mid.ru/bdomp/spd_md.nsf/0/7AC0A4FE053A138043257FE10046AD43.

16. http://www.gazpromexport.ru/partners/turkey/.

17. BOTAS Petroleum Pipeline Corporation (BOTAS), http://www.botas.gov.tr

18. Türkiye Petrolleri Anonim Ortaklığı (TPAO), http://www.tp.gov.tr/tp5/.

19. Ceyhan-Kırıkkale Petrol Boru Hattı, Batman-Dörtyol Petrol Boru Hattı, Şelmo-Batman Ham Petrol Boru Hattı, http:// petrol-petroleum.blogspot.ru/p/mevcut-boru-hatlarimiz.html.

20. Marmara Ereğlisi Liquefied Natural Gas (LNG), http://www.istanbul34.com.tr/Web/Link/BOTAS\%20TERMINAL\%20 M\%20ERE\%C4\%9EL\%C4\%B0S\%C4\%B0\%20TKRD\%C4\%9E.htm.

21. Baku-Tbilisi-Ceyhan Pipeline, http://www.bp.com/en_az/caspian/operationsprojects/pipelines/BTC.html.

22. Arab Gas Pipeline, http://www.hydrocarbons-technology.com/projects/arab-gas-pipeline-agp/.

23. http://www.nabucco-pipeline.com/company/shareholders7/botas-as/botas.html.

24. Royal Dutch Shell, http://www.shell.com/.

25. http://uk.reuters.com/article/turkey-gas-shell-idUKL0219827620070202 of 02.02.2007.

26. Bosphorus Gaz Corporation, http://www.bosphorusgaz.com/.

27. «Trans-Balkanskii» gazoprovod nachal funktsionirovat' v 1987 godu.

28. http://www.vestifinance.ru/articles/60770 of 31.07.2015.

29. http://www.gazprom.ru/press/news/2014/december/article208495/.

30. http://www.gazprom.ru/press/news/2014/december/article208495 of 02.12.2014.

31. http://ria.ru/trend/Russia_transadriatic_pipeline_06122014/\#ixzz46MkVXa6W, http://www.euractiv.com/section/ global-europe/news/russia-says-south-stream-project-is-over/ of 02.12.2014.

32. http://www.euractiv.com/section/global-europe/news/tsipras-turkish-stream-will-have-another-name-on-greekterritory/ of 09.04.2016.

33. http://www.gazprom.ru/press/news/2014/december/article208495 of 02.12.2014.

34. https://www.vedomosti.ru/business/articles/2016/09/07/656082-gazprom-potok of 07.09.2016.

35. http://www.euractiv.com/section/europe-s-east/news/bypassing-ukraine-will-be-costly-for-gazprom-say-analysts/ 17.07.2015.

36. http://www.euractiv.com/section/europe-s-east/news/us-discourages-greece-from-turkish-stream/ of 13.05.2015; Saipem, http://www.saipem.com/sites/SAIPEM_en_IT/home/saipem-homepage.page.

37. http://www.gazprom.ru/press/news/2014/december/article208495 of 02.12.2014.

38. «Rossiiskaya gazeta» ot 16.11.2015, http://rg.ru/2015/11/16/potok1-site.html.

39. http://www.vestifinance.ru/articles/52461 ot 27.01.2015.

40. http://www.gazprom.ru/press/news/2015/february/article217552/ of 07.02.2015.

41. http://www.gazpromexport.ru/projects/6/.

42. http://www.vestifinance.ru/articles/60770 of 31.07.2015.

43. http://crimea.ria.ru/world/20150804/1100605732.html of 04.08.2015.

44. http://crimea.ria.ru/world/20150804/1100605732.html of 04.08.2015.

45. https://www.consultant.ru/law/hotdocs/44842.html.

46. http://government.ru/media/files/GRARiHdNIWbl10wUg3LyPSAJPIDeTnLX.pdf.

47. «Rossiiskaya gazeta», http://rg.ru/2015/12/03/novak-site.html of 03.12.2015; https://www.rt.com/business/324230gazprom-turkish-stream-cancellation/ of 02.12.2015; http://izvestia.ru/news/598076\#ixzz45hiPjq1Z of 03.12.2015; http://www.euractiv.com/section/europe-s-east/news/russia-shelves-turkish-stream-pipeline-project/ of 03.12.2015.

48. https://www.euractiv.com/section/europe-s-east/news/russia-shelves-turkish-stream-pipeline-project/ of 03.12.2015.

49. http://kremlin.ru/events/president/transcripts/52125 of 07.06.2016.

50. http://kremlin.ru/events/president/news/52282 of 27.06.2016; http://tass.ru/politika/3514217; http://www. nytimes.com/2016/06/28/world/europe/russia-turkey-erdogan-putin.html?action=click\&contentCollection=Europe \& module=RelatedCoverage $® i$ ion=EndOfArticle\&pgtype=article of 27.06. 2016.

51. http://government.ru/news/24004/ ot 26.07.3016.

52. http://tass.ru/opinions/interviews/3518845 of 08.08.2016; http://www.euractiv.com/section/energy/news/russiaturkey-rapprochement-revives-turkish-stream-pipeline-talks/of 09.08.2016.

53. http://www.kremlin.ru/events/president/news/52671 of 09.08.2016.

54. http://www.kremlin.ru/events/president/news/52675 of 09.08.2016.

55. http://www.gazpromexport.ru/projects/6/.

56. http://www.gazprom.ru/press/news/2016/september/article283085/ of 07.09.2016. 
57. http://www.gazprom.ru/press/news/2016/september/article287217/ of 29.09.2016.

58. https://ria.ru/economy/20160930/1478235850.html.

59. http://www.kremlin.ru/events/president/news/53039 of 05.10.2016.

60. http://www.euractiv.com/section/energy/news/greece-macedonia-serbia-and-hungary-discuss-turkish-stream/ of 07.04.2015; http://kommersant.ru/doc/2703855 of 08.04.2015.

61. Joint Declaration on the Strengthening of Energy Cooperation of 07.04.2015, http://www.kormany.hu/en/ministryof-foreign-affairs-and-trade/photo-galleries/joint-declaration-on-the-strengthening-of-energy-cooperation; http:// www.mfa.gr/en/current-affairs/top-story/joint-declaration-on-the-strengthening-of-energy-cooperation-budapestapril-2015.html.

62. http://www.nytimes.com/2015/05/09/business/international/greece-us-russia-energy-pipeline.html of 09.05.2015.

63. Trans Adriatic Pipeline (TAP), http://www.tap-ag.com/.

64. Trans Anatolian Pipeline (TANAP), http://www.tanap.com/tanap-project/why-tanap/.

65. http://www.nytimes.com/2015/05/09/business/international/greece-us-russia-energy-pipeline.html of 09.05.2015.

66. SOCAR, http://www.socar.az/socar/az/home/.

67. Statoil, http://www.statoil.com/en/Pages/default.aspx.

68. Fluxys, http://www.fluxys.com/.

69. Enagás, http://www.enagas.es/portal/site/enagas.

70. Axpo, https://www.axpo.com/axpo/global/en/home.html.

71. http://www.bbc.com/russian/international/2014/09/140920_azerbaijan_europe_pipeline_launch.shtml.

72. http://oilprice.com/Latest-Energy-News/World-News/Greece-May-Be-Key-Player-In-European-Energy-Security.html of 11.05.2015.

73. http://oilprice.com/Latest-Energy-News/World-News/Greece-May-Be-Key-Player-In-European-Energy-Security.html, 11.05.2015.

74. http://oilprice.com/Latest-Energy-News/World-News/Greece-May-Be-Key-Player-In-European-Energy-Security.html, 11.05.2015.

75. http://www.nytimes.com/2015/05/09/business/international/greece-us-russia-energy-pipeline.html of 09.05.2015.

76. Antony J. Blinken, Deputy Secretary of State, Telephonic Press Briefing With European Journalists, http://www.state. gov/s/d/2015/242054.htm of 08.05.2015.

77. Antony J. Blinken, Deputy Secretary of State, Telephonic Press Briefing With European Journalists, http://www.state. gov/s/d/2015/242054.htm of 08.05.2015.

78. http://www.euractiv.com/section/global-europe/news/tsipras-turkish-stream-will-have-another-name-on-greekterritory/ of 09.04.2015.

79. http://www.gazpromexport.ru/projects/6/.

80. http://kremlin.ru/events/president/news/49220 of 08.04.2015.

81. http://kremlin.ru/events/president/news/49220 of 08.04.2015.

82. http://www.euractiv.com/section/energy/news/borissov-i-told-merkel-bulgaria-plans-pipeline-similar-to-nordstream-2/ of 17.12. 2015.

83. http://www.euractiv.com/section/energy/news/borissov-i-told-merkel-bulgaria-plans-pipeline-similar-to-nordstream-2/ of 17.12.2015.

84. http://www.euractiv.com/section/energy/news/south-stream-to-become-bulgarian-stream/ of 14.01.2016.

85. http://www.euractiv.com/section/energy/news/south-stream-to-become-bulgarian-stream/ of 14.01.2016.

86. http://www.euractiv.com/section/energy/news/south-stream-to-become-bulgarian-stream/ of 14.01.2016.

87. http://putin24.info/dvazhdy-v-odin-potok.html of 08.10.2015; http://m.novostimira.com/news-161460.html of 08.10.2015.

88. http://www.gazprom.ru/press/news/2016/october/article288205/ of 10.10.2016.

89. http://www.gazprom.ru/press/news/2016/october/article288205/ of 10.10.2016.

90. http://kremlin.ru/events/president/news/53062 of 10.10.2016. 